\title{
MOTIVASI KEBUTUHAN AKAN PENCAPAIAN MERRY PADA NOVEL MERRY RIANA MIMPI SEJUTA DOLLAR KARYA ALBERTHINE ENDAH
}

\author{
Yunita Anas Sriwulandari \\ Program Studi Pendidikan Bahasa dan Sastra Indonesia \\ IKIP Budi Utomo Malang \\ Jalan Citandui 46 Malang
}

\begin{abstract}
A healthy human consciousness, will be controlling his behavior. Normal behavior is motivated through the conscious process, psychologically most of a person's behavior is motivated by conscious thought. Motivation is the driving force that makes a person willing and able to exploit the ability in everythings, power and also times for achievement. Motivation is a state within the individual that drives behavior toward achievement. Everyone's motivation is always different. Motivation is usually studied on the novel character, the term character leads to the perpetrators of the story. Motivation will be more profound if it is realized that every human being has a need that is the need for an achievement. Novel Merry Riana The One Million Dollar Dream by Alberthine Endah deserves to be the object of research, as it presents the motivations and life journey of Merry's never give up, hardworking, persistent, disciplined, religious and confident to reach her dreams of success. The life principle of Merry Riana in this novel deserves to be an example or a role models for a confused reader living a life full of challenges.
\end{abstract}

Keywords: Motivation, needs of achievement, dreams of a million dollar.

Motif sebagai pendorong pada umumnya tidak berdiri sendiri, tetapi saling berkaitan dengan faktor-faktor lain, hal-hal yang dapat mempengaruhi motif disebut motivasi. (Walgito, 2010:240). Kata motivasi berasal dari kata "motive" atau "motiwion" yang berarti "a moving cause" yang berhubungan dengan "inner drive impulse intention". Kata "motive" ini berkembang menjadi motivasi artinya menjadi sedang digerakkan atau telah digerakkan oleh sesuatu dan apa yang menggerakkan itu terwujud dalam tindakan. Motivasi berasal dari bahasa latin yaitu " movere" yang artinya " to move". Jadi motivasi dapat diartikan sebagai proses yang membangkitkan, menggerakkan, dan mempertahankan perilaku. Branca (Walgito, 2010:240)

Individu yang sehat, kesadarannya mengontrol tingkah lakunya. Tingkah laku yang normal dimotivasi melalui proses sadar, secara psikologis sebagian besar tingkah laku seseorang dimotivasi oleh fikiran sadar. (Alwisol, 2012:229)

Motivasi adalah daya penggerak yang membuat seorang mau dan sanggup mengeluarkan kemampuan dalam bentuk keahlian atau keterampilan apapun, tenaga daya dan waktunya untuk melaksanakan segala kegiatan yang menjadi tanggung jawabnya dalam pencapaian tujuan dan berbagai sasaran. Motivasi pada diri seseorang tidak sama, berbeda-beda melihat karakter orang tersebut. (Siagian, 2002:138). Motivasi biasanya dikaji pada tokoh-tokoh dalam sebuah novel, istilah tokoh menuju pada pelaku ceritanya. Tokoh-tokoh dalam sebuah cerita fiksi dapat dikategorikan ke dalam beberapa jenis. Dengan kata lain tokoh adalah orang yang menjadi pelaku dalam cerita fiksi atau drama. Abram (Nurgiyantoro, 2015:247).

Motivasi merupakan keadaan dalam diri individu yang mendorong perilaku kearah tujuan. (Walgito, 2010:240). Dengan demikian dapat dikemukakan bahwa motivasi itu mempunai 3 aspek: 1) Keadaan terdorong dalam diri organism (a driving state) yaitu kesiapan bergerak karena kebutuhan misalnya kebutuhan jasmani, karena keadaan lingkungan, atau karena keadaan mental seperti berfikir dan ingatan. 2) Perilaku yang timbul dan terarah karena keadaan ini. 3) Goal atau tujuan yang dituju oleh perilaku terssebut.

Pada umumnya motivasi mempunyai sifat siklus (melingkar), yaitu motivasi timbul, memicu perilaku tertuju kepada tujuan (goal), dan akhirnya setelah tujuan (goal) tercapai motivasi itu berhenti. Tetapi itu akan kembali kepada 
keadaan semula apabila ada suatu kebutuhan lagi. Motivasi dapat bersumber dari dalam diri seseorang, yang dikenal dengan istilah motivasi internal atau motivasi intrinsik. Motivasi bersumber dari luar diri orang, yang dikenal dengan istilah motivasi eksternal atau motivasi ekstrinsik, dapat bersifat positif dan dapat bersifat negatif. (Siagian, 2012: 139).

Pemahaman motivasi akan semakin mendalam jika disadari bahwa setiap manusia mempunyai kebutuhan yaitu kebutuhan untuk sebuah pencapaian, (need for achievemen). Cleland (Siagian, 2002:167). Kebutuhan akan pencapaian atau prestasi (need for achievement) adalah kebutuhan sesorang untuk keberhasilan dalam hidup, setiap orang ingin dipandang berhasil dalam hidupnya, keberhasilan itu mencakup seluruh segi kehidupan seseorang. (Siagian, 2002:167). Dengan kata lain setiap orang ingin dipandang berhasil dalam kehidupannya.

Orang yang mempunyai kebutuhan atau need akan meningkatkan kemampuan, sehingga akan terlihat kemampuan prestasinya. Penelitian menunjukkan bahwa orang yang mempunyai need achiement tinggi, akan mempunyai prestasi yang lebih baik dibandingkan dengan orang yang mempunyai need achiement rendah. Dapat diketahui bahwa orang yang intelegent akan dengan senang hati menghadapi tugas-tugas yang sulit, dan ini akan mendorong need achiement-nya, dan berhubungan dengan performance-nya. (Walgito, 2010:249).

Seseorang dengan $n$ Ach adalah orang yang berbuat sesuatu, lebih baik dibandingkan dengan orang lain. Seseorang dengan $n A$ ch biasanya berusaha menemukan situasi dimana dia dapat menunjukkan keunggulannya, seperti dalam pengambilan keputusan dan melakukan sesuatu yang dapat dicapainya, dorongan yang kuat dalam dirinya bertanggung jawab terhadap keberhasilan dan kegagalan dalam melaksanakan tugas dan tanggung jawabnya dan tidak melemparkan kepada orang lain.

Kebutuhan akan suatu pencapaian pada dasarnya dimiliki setiap orang, keberhasilan meraih impian, cita-cita dan prestasi yang akan diusahakan dengan kerja keras untuk suatu keberhasilan. Kebutuhan dalam pencapaian terkaji dalam seorang tokoh Merry yang mau merubah hidunya dengan motivasi yang ada pada dirinya, yang terkaji pada sebuah novel berjudul Merry Riana Mimpi Sejuta Dollar karya Alberthine Endah.

Novel Merry Riana Mimpi Sejuta Dollar karya Alberthine Endah pantas dijadikan obyek penelitian, karena menyajikan tentang motivasi serta perjalanan hidup tokoh utama yang pantang menyerah, pekerja keras, gigih, disiplin, religius dan percaya diri untuk menggapai mimpi-mimpinya menjadi sukses. Prinsip hidup Merry Riana sebagai tokoh utama dalam novel ini patut menjadi teladan dan contoh bagi pembaca yang sedang bingung menjalani kehidupan yang sarat dengan tantangan.

Novel Merry Riana Mimpi Sejuta Dollar kaya Alberthine Endah ini sangat menginspirasi para pembaca untuk terus berusaha meraih kesuksesan yang diharapkan dan yang dicitacitakan. Novel ini merupakan best seler tahun 2012 dan saat ini Merry Riana merupakan wanita motivator No 1 di Indonesia karena kesuksesannya yang menginspirasi banyak orang baik di Singapura maupun di Indonesia.

\section{METODE}

Jenis penelitian yang digunakan dalam novel "Merry Riana Mimpi Sejuta Dolar" karya Alberthiene Endah adalah bersifat deskriptif kualitatif. Metode deskriptif merupakan cara penelitian dengan mengumpulkan data yang berisi kutipan kalimat untuk memahami kejadian apa yang dialami oleh subyek penelitian misalnya perilaku, motivasi, perilaku, dan lainnya dalam bentuk kalimat. (Moleong, 2016:11).

Data dalam penelitian ini berupa kalimat yang terdapat pada novel Merry Riana Mimpi Sejuta Dollar karya Alberthine Endah, yang diterbitkan oleh PT Gramedia Pustaka Utama, Jakarta pada tahun 2012.

\section{HASIL DAN PEMBAHASAN}

Seperti yang telah diuraikan di atas, bahwa novel Merry Riana Mimpi Sejuta Dollar karya Alberthine Endah, adalah novel motivasi. Motivasi perjalanan hidup tokoh Merry yang menginspirasi banyak orang, bukan hanya novel motivasi tetapi novel ini berisi banyak pelajaran hidup yang patut diteladani. Perjuangan sosok “Merry Riana" sebagai tokoh sentral yang semangat, gigih berjuang dan pantang menyerah dalam menghadapi kesulitan-kesulitan hidup menjadi pusat dalam cerita ini. 
Motivasi tokoh Merry pada novel Merry Riana Mimpi Sejuta Dollar karya Alberthine Endah, dengan menggunakan teori Kebutuhan Akan Pencapaian "Need for Achievement (nAch)" akan mengupas kebutuhan-kebutuhan sosok "Merry Riana" sebagai tokoh pusat. Berikut hasil penelitian dan pembahasan novel Merry Riana Mimpi Sejuta Dollar karya Alberthine Endah.

Hasil penelitian dalam novel Merry Riana Mimpi Sejuta Dollar karya Alberthine Endah, yang berhubungan dengan pencapaian tokoh utama yaitu Merry Riana adalah: keberhasilan dalam pendidikan, keberhasilan keluar dari masa-masa sulit di Universitas, keberhasilan dalam pencapaian karir yang sukses di usia muda. Kebutuhan untuk berhasil, tercermin karena adanya dorongan untuk meraih kemajuan dan pencapaian prestasi sesuai dengan standart yang telah ditetapkan. (Siagian, 2012:168).

Motivasi kebutuhan akan pencapaian dapat dilihat pada pekerjaan yang akan diambil sosok "Merry Riana" sebagai tokoh utama pada novel tersebut, dengan mengesampingkan rasa malu terhadap teman-temannya, karena "Merry Riana" pada saat itu adalah seorang mahasiswa baru, tentunya sangat mempengaruhi psikis Merry, karena pada saat itu usianya yang masih 18 tahun. Pekerjaan itu sangat dibutuhkan Merry untuk memenuhi kebutuhannya seperti tambahan uang makan, uang untuk membeli buku-buku kuliah dan penunjang kehidupannya selama menjadi mahasiswa NTU (Nanyang Tehcnologi University). Karena pada saat itu "Merry Riana" hanya mempunyai sepuluh dollar untuk biaya hidup dalam satu minggu.

Selain itu kutipan lain yang menunjukkan motivasi kebutuhan akan pencapaian. Berikut kutipan novel tersebut:

"Yang kupikirkan saat itu, aku harus melakukan sesuatu untuk memperbaiki keadaan. Tak perlu malu dan gengsi atas jenis pekerjaan yang kulakukan, karena toh pekerjaan itu bukan sesuatu yang nista." (nAch, 2013:144).

Dari kutipan tersebut motivasi kebutuhan akan pencapaian dapat dilihat pada pemikiran "Merry Riana" untuk perbaikan kehidupannya kedepan, karena dengan biaya yang pas-pasan bahkan sangat kurang dia harus bertahan hidup, hanya dengan sepuluh dollar untuk satu minggu ia harus bisa bertahan hidup. Dia meyakinkan dirinya untuk tidak malu dan gengsi menjalani pekerjaan sebagai seorang salles pembagi brosur, karena pekerjaan itu bukan pekerjaan yang nista.

Selain kutipan tersebut ada kutipan lain yang menunjukkan motivasi kebutuhan akan pencapaian.

"Aku telah memiliki resolusi. Kesusahanku hari ini, walau akhirnya disudahi dengan rasa riang, telah menyadarkanku. Aku tidak mau dibelenggu oleh kemiskinan terus-menerus. Aku harus sukses. Harus sukses! Dua kata itu berdengung dan menggema di sekujur hatiku. Harus suksaes!." (nAch, 2013:154).

Motivasi kebutuhan akan pencapaian dapat dilihat dari kata "harus sukses". Sosok "Merry Riana" sebagai tokoh utama meyakinkan dirinya sendiri bahwa ia harus meraih kesuksesan di usia muda, ia tidak mau hidup dengan keterbatasan dibelenggu oleh kemiskinan. Hidup yang serba kekurangan hanya menyantap mie rebus tiap hari untuk mengganjal perutna yang kosong, membuatnya bangun dari tidur untuk menggapai mimpi dan cita-citanya. Hidupnya harus segera berubah, dan ia mempunyai target bisa lulus dari NTU (Nanyang Tehcnologi University), dan mempunyai kehidupan yang baik. Kesuksesan adalah mimpi besar yang akan diraihnya, bahkan ia memiliki resolusi dalam kehidupannya. Resolusi harus sukses. Selain itu terdapat pula kalimat yang menunjukkan pencapaian terbesarnya.

"Inilah yang pantas kita renungkan. Bahwa ada sesuatu yang sangat misterius, kekuatan yang demikian dahsyat yang tersembunyi di balik situasi sulit. Di dalam fase hidup yang berat orang-orang secara alamiah mengeluarkan fitur-fitur yang terkubur. Tiba-tiba kekuatan itu ada. Mendadak kemauan itu muncul. Tahu-tahu kita sudah terbentuk menjadi orang yang sangat tangguh. Itu bagi orang yang mau berjuang. Tapi banyak juga orang yang terjebak dalam kondisi sulit dan diam saja. (...) Yang paling menyengat adalah muncul cita-cita yang kuat. Resolusi, kehendak kuat untuk bisa menjadi manusia mapan dan sukses menyeruak dan menggedor-gedor hatiku. (nAch, 2013:162).

Pencapaian dapat dilihat dari motivasi "Merry Riana" sebagai tokoh utama yang mempunyai resolusi dalam hidupnya, resolusi untuk hidup mapan dan sukses yang seakanakan menjadi motor penggerak Merry untuk bergerak maju untuk meraih sukses. Ia meyakini ada sesuatu yang misterius yaitu kekuatan yang dahsyat tersembunyi dibalik situasi-situasi sulit 
yang dimiliki setiap orang. Kekuatan itu membentuk seseorang menjadi tangguh berjang mencapai mimpi besar dan cita-citanya.

"Aku sudah menetapkan resolusi untuk sukses di usiaku ke-20. Sebelum aku ulang tahun ke-30, aku harus sudah bisa memiliki kebebasan finansial, dimana aku tidak perlu khawatir lagi akan soal keuangan, bisa melunasi hutang dan hidup dengan nyaman. Rencana konkretnya akan seperti apa, aku belum tahu. Yang jelas, telah tumbuh dalam diriku sebuah tekad yang sangat kuat. Tekad yang memimpin harapan dan pola pikirku untuk senantiasa mengembangkan diri dan mencari peluang. Ini merupakan tahapan penting sebelum aku melakukan langkah-langkah selanjutnya." (nAch, 2013:166).

Pencapaian dapat dilihat dari semangat "Merry Riana" yang mempunyai resolusi dalam hidupnya, bahwa di usia ke-20 sebelum ulang tahun ke-30, ia harus sudah bisa memiliki kebebasan finansial. Rencana seperti apa kedepannya ia belum mengetahuinya tapi tekad yang sangat kuat membuatnya mempunyai pola pikir membangun diri mencari peluang-peluang untuk mewujudkan impiannya menjadi wanita sukses di usia muda. Harapan dan kerja keras ia tanamkan dalam hatinya, sehingga itu sebagai semangat untuk mendapatkan pencapaian dalam kehidupannya.

Selain kutipan tersebut kutipan lain yang menunjukkan motivasi kebutuhan akan pencapaian.

"Dalam kondisi sulit kita tetap bisa mendapatkan peluang. Kita harus optimis dan tidak menyerah pada keadaan. Kepekaan kitapun harus tajam sehingga kita bisa mengatur langkah-langkah yang berpotensi menguntungkan, ditengah situasi apapun." (nAch, 2013:173).

Motivasi kebutuhan akan pencapaian dapat dilihat dari sikap "Merry Riana" yang selalu optimis dan tidak mau menyerah pada keadaan sulit yang ia alami, ia mengasah kepekaan untuk mengatur strategi dan langkahlangkah untuk kehidupan yang lebih baik.Peluang-peluang untuk mewujudkan impiannya menjadi wanita sukses dan mempunyai kebebasan financial di usia muda. Merry Riana untuk berjuang, mengerti arti perjuangan yang sesungguhnya. Bukan hanya ambisi dan angan-angan yang tidak akan pernah direalisasikan, tapi perjuangan harus ada strategi, keuletan dan inovasi. Tidak menunda-nunda perjuangan tetapi dengan bekerja keras untuk mengubah nasib, karena nasib sebenarnya ada di tangan kita. Kata-kata "Merry Riana" sangat memotivasi pembaca yang sedang kendor dan putus asa menjalani kehidupan tentunya masalah pasti akan selalu ada. Merry Riana mengajarkan kita untuk selalu optimis dan bekerja keras untuk mengubah nasib.

Meyakinkan dirinya untuk mengerahkan semua kekuatan untuk menggapai kesuksesan. Ia akan mengalahkan keragu-raguan yang muncul bahwa dirinya bisa meraih mimpi untuk sukses di usia muda. Pencapaian untuk sukses di usia sebelum 30 tahun telah menjadi tujuan dan resolusinya, secara nyata telah mempengaruhi jiwanya sehingga ia sangat brsemangat meraih mimpinya walau kerja keras akan ia lakukan untuk mendapatkan kebebasan financial dan membahagiakan keluarga dan orang-orang terdekatnya.

"Hal terpenting yang kutuai dari Anthony Robbins adalah pembuktian akan keajaiban dari keberanian. Setelah berhasil bertemu dengannya dan berfoto bersama, aku yakin akan kekuatan tekad di diriku yang bisa menebas ketidakmungkinan. Keberhasilan berfoto dengan Anthony Robbins bukan semata perjuangan menuju selembar foto dengan tokoh terkenal. Keberhasilan itu telah membangun satu kepercayaan diri yang semakin keras di diriku. Aku tidak lagi ragu pada kemungknan-kemungkinan sukses yang bisa kuburu." (nAch, 2013:256).

Dari kutipan tersebut motivasi kebutuhan akan pencapaian dapat dilihat dari keberanian sosok " Merry Riana" untuk mengejar mimpi salah satunya mimpi bertemu dengan Anthony Robbins telah terwujud. Sehingga semakin kuat keyakinannya bahwa ia bisa meraih sukses, karena kekuatan dan tekad yang ada pada dirinya menebas ketidakmungkinan. Merry Riana telah yakin akan kepercayaan dirinya untuk mengejar kesuksesan dengan membangun kepercayaan diri yang semakin keras di hatinya.

Peka memburu peluang-peluang bisnis yang ada, karena ia sangat ingin membahagiakan kedua orangtuanya. Ia telah menemukan jalan yang mulus dan menentukan tujuan pekerjaannya untuk mendapatkan uang dengan cepat, dan mimpinya adalah membayar hutang pendidikannya selama kuliah di NTU. Supaya orangtuanya terbebas dari hutang tersebut, karena Merry Riana tahu bahwa keluarganya 
mengalami krisis financial. Untuk membahagiakan orantuanya, dan ia akan membuktikan kepada banyak orang bahwa kerja keras bisa mengubah nasib, kerja keras bukan suatu yang mustahil untuk melepaskan belitan kemiskinan.

"Targetku jelas, ingin sukses financial di usia muda. Jika perahu untuk mencari target itu adalah klien-klienku, walau harus menemui jalan apapun, aku siap! Aku bisa, pasti bisa! Pelajaran penting yang bisa diambil dari fase ini adalah tidak putus asa, terus mencari jalan keluar terbaik, dan berani menghadapi tantangan." (nAch, 2013:323).

Pencapaian dapat dilihat dari target-target sosok Merry Riana, bahwa sukses financial ada di depan mata. Klien-kliennya adalah jalan menuju sukses, untuk memuluskan tujuannya itu ia akan menempuh jalan apapun walau itu sulit. Ia tidak putus asa dan akan fokus kepada tujuannya untuk mencari jalan keluar yang terbaik, dan ia akan siap menghadapi tantangan, walau usianya masih sangat muda tetapi semangatnya luar biasa.

Untuk membahagiakan orangtuanya, adalah energy pendorong yang paling besar dalam kerja kerasnya. Keinginannya untuk membanggakan orangtua, adalah cita-cita utamanya. Sehingga ia dengan keras membangun motivasi dan kekuatan pada dirinya untuk mengejar mimpi itu menjadi kenyataan. Pada saatnya menduduki posisi manager pada awal tahun 2004. Karena kerja keras yang telah ia lakukan ia yakin bahwa sebentar lagi targettargetnya akan segera tercapai. Ia mampu membuktikan bahwa kerja keras adalah kunci dari keberhasilan, dan ia sangat bangga dengan pencapaian ini karena ukuran seorang sales baru yang mencapai target yang amat mencengangkan. Itulah salah satu keberhasilan Merry Riana membangun semangat dan menentukan target-targetnya melunasi hutang pendidikannya sebesar 40 ribu dolar.

“Tahun 2004 kusambut dengan penuh sukacita. Aku dipastikan menjadi Presiden Star Club karena pencapaianku yang terus bertambah. Saat itu penghasilan yang kucapai sudah sampai sati miliar rupiah lebih per tahun. Itu gaji yang jauh melampaui teman-teman seangkatanku yang bekerja di perusahaan-perusahaan. Dan jumlah itu akan terus bertambah mengiringi perkembangan pencapaianku." ( nAch, 2013:376).
Dari kutipan tersebut motivasi kebutuhan akan pencapaian dapat dilihat dari kesuksesan besar yang diraih oleh Merry Riana. Sekali lagi pencapaian menjadi seorang Presiden Star Club ia raih, berkat kerja keras dan kegigihannya dalam menggapai mimpi dan merealisasikan target-targetnya semakin mengiringi langkahnya. Cucuran keringat dan air mata mengiringi langkahnya menggapai puncak kesuksesannya ini. Dan support seorang Alva yang mampu manggugah semangat serta kekuatan pada dirinya untuk bertahan dalam kesulitan. Presiden Star Club bukan jabatan yang main-main dan tidak sembarangan orang mampu berada pada posisi ini, melihat sosok Merry Riana perempuan muda yang mampu menggapai mimpi-mimpi dan targetnya dalam waktu singkat adalah bukti bahwa ia tidak main-main dalam pekerjaan ini.

Pencapaian dapat dilihat dari pencapaian kategori sales baru terbaik dan ia mampu memecahkan rekor tertinggi di Industri keuangan Singapura, ya rekor tertinggi. Ini adalah langka, dan baru pertama kalinya terjadi karena melihat sosok Merry Riana perempuan muda pendatang baru, ia baru menekuni bisnis ini tetapi ia mampu meraih kesuksesan luar biasa. Penghargaan Di Gold Coast bukan penghargaan yang main-main dan tidak sembarangan orang mampu berada pada posisi ini. Ini sungguh melengkapi kebanggaan Merry Riana, berawal dari seorang sales, naik menjadi managear tidak lama banyak penghaargaan ia raih, itu semua karena kerja keras dan kegigihannya serta mental yang luar biasa ia bangun berawal dari mahasiswa biasa yang penuh dengan keterbatasan ekonomi, menjadi meliuner muda yang sukses meraih penghasilan diatas rata-rata.

Motivasi kebutuhan akan pencapaian dapat dilihat dari semangat seorang Merry Riana mengembangkan bisnisnya dengan mendirikan MRO (Merry Riana Organization ). Yang berdiri karena kerja keras Merry Riana dan Alva sebagai pemilik dan pendiri organisasi tersebut. Merry sangat sadar bahwa pekerjaan di dunia sales marketing tidak akan selamanya cemerlang, ada jenjang yang sudah pasti. Jika saat ini ia sudah menjadi direktur utama berarti dia harus creative mencari manufer lain yang lebih menghasilkan. Pada akhirnya ia mendapatkan yang lebih dari mimpinya. Seperti pada kutipan berikut. 
"Aku mendapatkan apartemen mungil yang cukup nyaman di lantai 11. Posisi kondominium itu tidak jauh dari kantorku di Fuji Xerox Towers, Tanjong Pagar. Aku juga membeli sebuah Mercedes dengan harga 1,5 miliar rupiah. Sedan itu sengaja kubeli dengan satu alasan khusus. Anak-anak buahku akan terinspirasi untuk bisa menjadi sukses setelah bisa melihat keberhasilankumemapankan diri. Dan sedan itu menjadi symbol kemapanan." ( nAch, 2013:398).

Motivasi kebutuhan akan pencapaian dapat dilihat dari kebebasan financial yang didapatkan oleh Merry Riana, Merry telah membuktikan pencapaian demi pencapaian telah ia raih. Sukses di masa muda sebagai mimpinya sudah terwujud, itu tidak sekedar menjadi angan angan saja melainkan menjadi kenyataan karena kerja keras dan perjuangan yang ia lakukan. Kebebasan financial tentu akan selalu mengiringi langkahnya, karena posisinya bukan lagi sebagai sales pembagi brosur atau sales sebuah asuransi, melainkan pemilik dan pendiri MRO (Merry Riana Organization ). Karena pencapaian itu posisi hunian yang nyaman telah Merry pilih, kondominium yang nyaman, dan sebuah mobil mewah Mercedes dengan harga 1,5 miliar rupiah bisa ia wujudkan sebagai simbol keberhasilannya meraih sukses.

\section{KESIMPULAN}

Berdasarkan hasil paparan tersebut, diperoleh simpulan berkaitan dengan motivasi kehidupan tokoh Merry Riana Mimpi Sejuta Dollar karya Alberthne Endah, bahwa novel tersebut mengandung motivasi yang dikembangkan pada motivasi akan pencapaian (Need for Achievemen), kebutuhan akan suatu pencapaian pada dasarnya dimiliki setiap orang, tidak terkecuali Merry Riana sebagai tokoh utama dalam novel tersebut. Keberhasilan meraih impian, cita-cita dan prestasi yang dicapai diusahakan dengan kerja keras, kegigihan dan keuletan, yang akhirnya berbuah pada sebuah keberhasilan yang lebih dari yang diimpikan, kemapanan ekonomi yang pada akhirnya membuat diri dan orangtuanya terbebas dari belitan hutang. Semuanya butuh usaha dan kerja keras untuk mengubah nasib dirinya, motivasi yang tinggi, pada akhirnya membuat merubah segala masalah tentang hidupnya.

\section{SARAN}

Individu yang sehat, kesadarannya mengontrol tingkah lakunya. Tingkah laku yang normal dimotivasi melalui proses sadar, secara psikologis sebagian besar tingkah laku seseorang dimotivasi oleh fikiran sadar. Motivasi adalah daya penggerak yang membuat seorang mau dan sanggup mengeluarkan kemampuan dalam bentuk apapun, tenaga daya dan waktunya untuk melaksanakan segala kegiatan yang menjadi tanggung jawabnya dalam pencapaian tujuan dan berbagai sasaran. Motivasi dapat bersumber dari dalam diri seseorang, yang dikenal dengan istilah motivasi internal atau motivasi intrinsik.

Pemahaman motivasi akan semakin mendalam jika disadari bahwa setiap manusia mempunyai kebutuhan yaitu kebutuhan untuk sebuah pencapaian, (need for achievemen).

\section{DAFTAR RUJUKAN}

Alwisol. 2009. Psikologi Kepribadian. Malang: UMM Press.

Endah, A. 2012. Merry Riana Mimpi Sejuta

Dolar. Jakarta: PT. Grameia Pustaka Utama.

Moleong, J. 2016. Metodologi Penelitian Kualitatif. Bandung: Penerbit PT. Remaja Rosdakarya Bandung.

Nurgiyantoro, B. 2015. Teori Pengkajian Fiksi. Yogyakarta: Gadjah Mada University Press.

Siagian, P. 2012. Teori Motivasi Dan Aplikasinya. Jakarta: PT. Rineka Cipta.

Walgito, B. 2010. Pengantar Psikologi Umum. Yogyakarta: C.V Andi Offset. 